$x w=79 x=9$

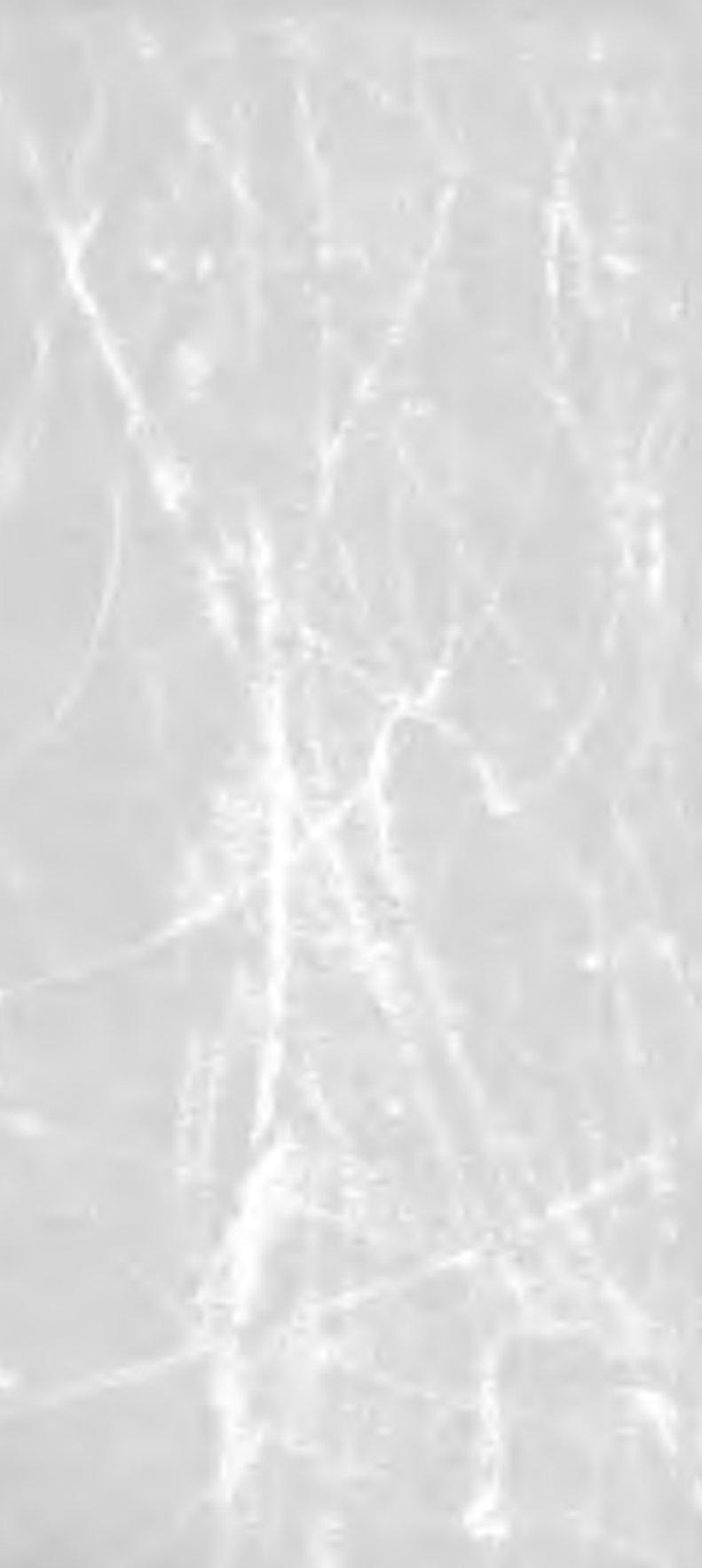




\section{Absurd uciekającego bytu ${ }^{*}$}

ABSTRACT. Tokarz Bożena, Absurd uciekającego bytu [The Absurdity of Being-on-the-Run]. "Przestrzenie Teorii" 3/4, Poznań 2004, Adam Mickiewicz University Press, pp. 9-19. ISBN 83232-1454-9. ISSN 1644-6763.

At the onset of the 21 st century art and literature emerge as a consequence of two orders: the past, that is the 20 th century, and the future, anticipated - by and large - on the basis of previous experiences.

The artistic consciousness of the past century is determined by contradictions, such as empathy and distrust, reason and sensation, rationalism and metaphysics, the subject and the object, the whole and the fragment. Leaving out one element in any of such oppositional pairs either leads to frustration, or to dogmatism, while the acceptance of their simultaneity - results in the removal of permanent points of reference in the sphere in which humans, objects, phenomena and values exist. In the 20th century, the loss of faith and the hardships of the quest for one's own identity led to a situation marked by absurdity: it caused the escape of being. The body flees from the man, theatricality runs away tram the theater, literariness escapes letters, literary scholarship flies from literature.

The lack of identity turns any being-bound quality into void - yet art, literature, culture and man continue to exist nonetheless, functioning by the principle of similarity and difference.

Problemy, które pojawiły się $\mathrm{w}$ drugiej połowie $\mathrm{XX}$ wieku, eksponowane w latach 80. i 90. jako zjawiska tzw. ponowoczesności, w kulturach europejskich narastały $\mathrm{w}$ czasie stulecia $\mathrm{z}$ różnym nasileniem $\mathrm{w}$ sztuce, literaturze i świadomości kulturowej. Będąc konsekwencją nowożytnego stosunku do świata w nauce i w filozofii, obraz artystyczny świadomości poprzedniego stulecia określa postulat empatii formułowany na początku z pozycji silnej podmiotowości i na końcu wieku w świetle doświadczeń podmiotu poszukującego ciągle własnej tożsamości. Te w efekcie odmienne podmiotowości realizowały się w różnych projektach: postulatywnych i wyraźnie określonych w propozycjach futurystów, ekspresjonistów czy konstruktywistów oraz w koncepcjach pełnych zwątpienia i mnożących się pytań w dobie ponowoczesnej. Towarzyszył im bowiem inny stosunek do świata: ujmowanego jako całość przez fenomenologię, intuicjonizm Bergsona, egzystencjalizm i jeszcze hermeneutykę pomimo dramatyzmu filozofii Nietzschego i wizji Freuda, w przeciwieństwie do

* Prezentowany tekst jest wersją referatu wygłoszonego na konferencji „Teatr - media - kultura" zorganizowanej z okazji Jubileuszu 50-lecia pracy naukowej prof. dr hab. Eleonory Udalskiej przez Zakład Wiedzy o Teatrze Instytutu Nauk o Kulturze Uniwersytetu Sląskiego w dn. 16-17 kwietnia 2004 roku w Ustroniu. 
zauważonego rozbicia całości, rozproszenia i nieufności do niej w koncepcjach Jacques'a Derridy, Gilles'a Deleuze'a, Jean-François Lyotarda, Jeana Baudrillarda i Richarda Rorty'ego.

Zygmunt Bauman wyróżnia postawy „prawodawców i tlumaczy” ze względu na stosunek podmiotu poznającego do świata i człowieka, obejmując obserwacją okres od XVII. do końca XX. wieku. Czas tłumaczy to według niego - doba ponowoczesności, otwierająca inną perspektywę rozumienia1. Dominującemu w niej poczuciu wątpliwości, braku stałości, zmienności towarzyszy chęć porozumienia się z Innym, jego zrozumienia i szacunku. Jednak potrzeba kontaktu z Innym głoszona przez Levinasa, choć wypływająca $\mathrm{z}$ empatii, nie pozostaje zawsze $\mathrm{w}$ bliskim związku $\mathrm{z}$ kulturą, literaturą, sztuką i myślą teoretyczną, gdzie zauważa się absurdalne zanikanie bytowości na rzecz śladów po niej. W miejsce jedności bytu pojawia się wielość odbić, form istnienia, utrudniających dostęp do jego istoty. Wynika to w tym samym stopniu z „różni” (différance) Derridy wywiedzionej z myślenia postrukturalistycznego i przekonania o kresie człowieka ${ }^{2}$, jak również $\mathrm{z}$ idei powtórzenia Deleuze'a ${ }^{3}$. Odrzucenie postawy „prawodawcy” prowadzi w kierunku absolutyzacji względności, czego wynikiem jest poczucie absurdu, ponieważ nastąpił rozdźwięk między bytem i świadomością, przedmiotem i podmiotem. „Ja” literackie oderwało się od podmiotu, co szczególnie widoczne stało się w konstrukcji podmiotu lirycznego, który skazany został bądź na skrajny subiektywizm (np. w poezji Jacka Podsiadły), bądź na przedmiotowość przekaźnika (np. Swiat 1906 - Collage, Non-stop-shows, Biale groszki Tadeusza Różewicza), bądź na wykorzenienie z przestrzeni, po której pozostał tylko ruch (w poezji Andrzeja Sosnowskiego). Literaturoznawstwo traciło swój przedmiot, czyli literaturę, w niektórych pracach Julii Kristevej, Jacques'a Derridy, Michała Pawła Markowskiego, stając się refleksją filozoficzną, kulturową, antropologiczną. Eksperyment w teatrze już nie tylko rozszerzał jego możliwości tworzywowe. $Z$ jednej strony teatr podjął walkę z fałszem wszelkich spektakli, zanegował teatralność sceny jako iluzję na rzecz autentyczności kontaktu $\mathrm{z}$ widzem (np. w Living Theatre), sięgnął po operowanie fragmentem, rozproszonymi obrazami (np. w Kartotece rozrzuconej Różewicza). Z drugiej - zaczął wykorzystywać w celach iluzyjnych środki nowych technologii (np. w teatrze kompute-

${ }_{1}$ Por. Z. Bauman, Prawodawcy i tlumacze, w: Postmodernizm. Antologia przekladów, red. R. Nycz, Kraków 1997, s. 269-298.

2 Por. J. Derrida, O gramatologii, przel. B. Banasiak, Warszawa 1999 oraz tegoż: Kres czlowieka, przel. P. Pieniążek, w: Pismo filozofii, przeł. B. Banasiak, K. Matuszewski, P. Pieniążek. Kraków 1992.

3 Por. G. Dełeuze, Różnica i powtórzenie, przel. B. Banasiak, K. Matuszewski, Warszawa 1997. 
rowym). Również film niekomercjalny zniszczył magię iluzji obrazu na rzecz przesuwających się skojarzeń obrazowych, obnażających powierzchowność kultury medialnej.

W wielu dziedzinach sztuki oraz w refleksji teoretycznej i krytycznej nad nimi zauważalna jest transgresywność, chęć przekraczania istniejących granic. Kategorialność opisów zastępuje skalarność, czyli mniejsze lub większe podobieństwo do uciekającego przedmiotu, który ujawnia lub ukrywa różne obszary swej istotności ze względu na przyjęty punkt widzenia. Przedmiot nie pojawia się w całej swej pełni, ciągle ukrywa jakąś tajemnicę, pozostając do końca nierozpoznawalnym. Wynikiem transgresyjności są formy nieczyste, hybrydyczne.

Krystyna Wilkoszewska, pisząc o postmodernizmie, zwraca uwagę, że pomimo trudności związanych $\mathrm{z}$ określeniem granic zakresowych i znaczeniowych tego pojęcia istnieją problemy dlań typowe, choć niejasno formułowane. Są to:

wyostrzone pytania o rozum i racjonalność, o rolę racjonalnego i humanistycznego oświecenia dla kulturalnego i politycznego oblicza zachodniego świata, problem przemocy nie tylko w sferze polityki i życia społecznego, ale i w teorii i w nauce, zagadnienie śmierci podmiotu i posthistoryczności, stosunek do kategorii prawdy, problemy nowej wrażliwości w obrębie świadomości artystycznej, analiza nowych, w związku z pojawieniem się w naszym życiu mediów na wielką skalę, sposobów postrzegania itd. ${ }^{4}$

Wymieniony zestaw problemów nie pojawił się nagle w ostatnim trzydziestoleciu minionego stulecia, lecz wątpliwości narastały już w dobie fascynacji i wiary w możliwości, jakie stwarzają człowiekowi nowe technologie XX wieku. Andrzej Turowski zauważa ukryty niepokój wewnątrz tak, wydawałoby się, apoteozującego technikę i naukę ruchu w sztuce, jakim był konstruktywizm, wymieniając między innymi nazwisko Szczuki i wyrastającego $\mathrm{z}$ tego nurtu Strzemińskiego ${ }^{5}$. Podobne zjawisko można zauważyć również $\mathrm{w}$ poezji polskiej istniejącej wewnątrz tego ruchu: w poematach Tadeusza Peipera Kronika dnia, Zniżka dolara i $\mathrm{Na}$ przykład czy w tomiku Juliana Przybosia Równanie serca, jakby wbrew głoszonej przez tych poetów ortodoksyjnej poetyce. Inaczej, bo jawnie, nadrealizm w programie André Bretona i w literaturze europejskiej upominał się o autentyczność. Pod wpływem psychoanalizy pokazywano rozbicie psychiczne jednostki między tym, co osobiste, a tym, co społeczne. Z. Bauman zauważył w wizji Freuda tragiczny rys dojrzałej cywilizacji nowożytnej,

${ }^{4}$ K. Wilkoszewska, Wariacje na postmodernizm, Kraków 2000, s. 9 (wyd. II).

5 Por. A. Turowski, Budowniczowie świata, Kraków 2000. 
[...] w której „zasada rzeczywistości” zdominowała „zasadę przyjemności”, w wyniku czego ludzie zrezygnowali z części swojej wolności (i szczęścia), uzyskując w zamian pewien stopień bezpieczeństwa [...]. Transakcja może być korzystna, ale jest wynikiem stłumienia „naturalnych" popędów oraz narzucenia takich wzorów zachowania, które nie bardzo pasują do predyspozycji człowieka, a przy tym oferują tylko pośrednie ujście dla instynktów i namiętności ${ }^{6}$.

Pomimo że sztuka od wieków pomagała człowiekowi zadomowić się w rzeczywistości, oswajając ją w geście artystycznym, to zwiększone znacznie w dwudziestym wieku możliwości komunikacyjne i informacyjne zaczęły dość wcześnie jej zagrażać przez interpretację zawartą w przekazywanych wiadomościach. Fakty zaczęły wyprzedzać sztukę, jak pisał Srečko Kosovel - jeden z poetów słoweńskich w latach 20. Swiat realny zawsze wymusza na sztuce konieczne zmiany, co w XX wieku zostało wyraźnie sformułowane w refleksji teoretycznej na temat zależności rozwoju sztuki od zmian zachodzących w rzeczywistości. Władysław Strzemiński w Teorii widzenia zwracał uwagę na to, że geneza różnych sposobów widzenia w sztuce tkwi w zjawiskach cywilizacyjnych, a Enkvist w pracach teoretycznych wskazywał na wpływ stylu epoki na styl sztuki? ${ }^{7}$. Cywilizacja techniczna i polityka, stając się konkurentami sztuki, wywołały m.in. takie zjawiska, jak zwielokrotnienie, powtórzenie, reprodukcja oraz zwątpienie w możliwość oryginalności.

$\mathrm{Na}$ początku wieku literatura i sztuka zajęły wobec rzeczywistości dwojakie stanowisko prowadzące do: estetyzacji życia i autonomizacji sztuki. Już propozycje futurystów wskazywały na potrzebę wyjścia sztuki na ulicę, co u Brunona Jasieńskiego znalazło m.in. wyraz w haśle o 24-godzinnym życiu poematu ${ }^{8}$. Rozwinęli to konstruktywiści w propozycjach „przemysłowych” Fernanda Légera oraz pracach Władimira Tatlina i Aleksandra Rodczenki. Równocześnie sztuka dążyła do specjalizacji, wykorzystując własne możliwości wewnętrzne (tworzywowe), a także realizując swoje ambicje poznawcze, co zrodziło suprematyzm Malewicza, unizm Strzemińskiego, poezję Peipera i Przybosia. Autonomia sztuki pozwalała artystom na inne niż naukowe poznanie rzeczywistości. O ile w przypadku estetyzacji przedmiot sztuki tracił swe ostre granice i zmierzał w kierunku wtopienia się w rzeczywistość, o tyle wynikiem drugiej postawy, zmierzającej do autonomizacji, było stworzenie wyraź-

${ }^{6}$ Z. Bauman, Prawodawcy i tlumacze..., s. 274.

7 Por. W. Strzemiński, Teoria widzenia, Kraków 1958; N. E. Enkvist, On Defining Style, w: N. E. Enkvist, J. Spencer, M. J. Gregory, Linguistics and Styl, Oxford 1964.

${ }^{8}$ Por. B. Jasieński, Manifest w sprawie poezji futurystycznej, w: Antologia polskiego futuryzmu i Nowej Sztuki, wstęp, komentarz, oprac. Z. Jarosiński, wybór, przygotowanie tekstów H. Zaworska, Wrocław 1978, s. 185-186. 
nych granic między sztuką a rzeczywistością (choć nowe formy artystyczne pochodziły z konceptualizacji rzeczywistości i kształtowały nową wrażliwość estetyczną). Autonomizując sztukę, artyści tworzyli świat alternatywny wobec rzeczywistego. W procesie tym dostrzegali, podobnie jak zawsze czyniła to sztuka, pęknięcia w postulowanym i znormalizowanym świecie rzeczywistym i równocześnie tworzyli własny jego obraz. Natomiast sygnałem zanegowania dotychczasowej funkcji sztuki były gesty Marcela Duchampa (wprowadzenie rzeczy w obszar percepcyjny sztuki oraz wykorzystanie reprodukcji Giocondy), który zwrócił uwagę na podważoną przez kulturę rolę artysty i dewaloryzację oryginalności. Do takiej negacji skłoniło go samo zjawisko reprodukcji jako niekończący się proces zwielokrotniania, prowadzący do zatarcia jednorazowości kreacji artysty oraz do wypaczenia jego dzieła.

Nic więc dziwnego, że w niewielkiej książeczce wydanej w 1928 r. Walter Benjamin pisał:

Konstrukcja życia pozostaje obecnie zdecydowanie bardziej w mocy faktów niż przekonań. I to takich faktów, które bodaj nigdy jeszcze i nigdzie nie stały się podstawą przekonań. W tych okolicznościach prawdziwa aktywność literacka nie może aspirować do rozgrywania się w ramach literackich - jest to raczej zwykły wyraz jej bezpłodności. Istotna działalność literacka może odbywać się tylko w ścisłej przemienności działania i pisania; musi w ulotkach, broszurach, artykułach prasowych i na plakatach wykształcać niepozorne formy, które lepiej odpowiadają jej wpływowi w czynnych wspólnotach niż pretensjonalny uniwersalny gest książki ${ }^{9}$.

A w innym miejscu dodawał:

Wszystkie rzeczy zatracają swój istotny wyraz w niepowstrzymanym procesie mieszania i zanieczyszczania, a miejsce tego, co właściwe, zajmuje dwuznaczność ${ }^{10}$.

Prezentowane stanowisko rozwinął $\mathrm{w}$ takich szkicach, jak: Twórca jako wytwórca, Tezy historiozoficzne czy Dzieto sztuki w dobie technicznej reprodukcji.

Pomimo sygnałów rozbicia przedmiotu i wewnętrznej złożoności podmiotu poznającego, co pokazała psychoanaliza, istniało pojęcie całości jako kategoria porządkująca. Organiczność istnienia wpisana w wizje historycznej awangardy sąsiadowała ze swym zaprzeczeniem w filmach Charlie Chaplina, przedstawiających inną, nienaturalną organiczność, czyli organiczność maszyny, która wciąga w swe tryby człowieka. Również w filozofii początku wieku istniała zapowiedź rozbicia jedności. Choć u podstaw epistemologii Husserla leżało przekonanie o istnieniu całości

${ }^{9}$ W. Benjamin, Ulica jednokierunkowa, przeł. A. Kopacki, Warszawa 1997, s. 7.

10 Tamże, s. 22. 
i wzajemnej korespondencji między częściami, to jego teoria czystej świadomości i egologia zainspirowały pytania Heideggera o bycie-wświecie, inaczej wpłynęły na charakter kategorii bytu w sobie i bytu dla siebie u Sartre'a oraz nie były obojętne dla Gadamera i jego hermeneutyki opartej na porozumieniu i rozmowie. Funkcję konsolidującą u Husserla pełniła świadomość, a u Bergsona - élan vital i intuicja. Te przeciwne bieguny scalające $\mathrm{w}$ filozofii Husserla i Bergsona są znamienne dla późniejszej, obecnej w drugiej połowie XX wieku dwutorowości refleksji filozoficznej i twórczości artystycznej. Dla postaw filozoficznych znamienny jest dekonstruktywizm, a dla artystycznych - transgresywność, empatyczne rejestrowanie śladów, oddzielenie przedmiotu od świadomości o nim.

Dlatego rozbicie przedmiotu w malarstwie kubistów miało cel artystyczno-poznawczy. Przedmiot pokazywany był równocześnie ze wszystkich stron, a więc całościowo. Rola podmiotu twórczego, artysty, obejmowała czynności poznawcze i kreacyjne. Podmiotowej kreacyjności były również poddane collages Picassa, jego papiers collés, ponieważ materia obca wzięta z rzeczywistości podlegała w nich sile kreacyjnej obrazu. Podobny przykład stanowi sensualizm Strefy Apollinaire'a widoczny w sposobie rejestrowania doznań zmysłowych i włączaniu zdarzeń. Zróżnicowany i rozbity świat ujęty jest $\mathrm{w}$ zamkniętej kompozycji poematu, obejmującej jak obręcz wycinek przedstawionej rzeczywistości Paryża. Całość poetycka została złożona z różnorodnych obserwacji.

Konstruktywizm, choć jego twórcy zakładali możliwość zorganizowania świata przez podmiot, eksponował przedmiot, wytwór artysty, przez który on sam mógł zaistnieć. Nastąpiło więc wyraźne uprzedmiotowienie podmiotu $\mathrm{w}$ jego wytworze. Upodmiotowił artystę na powrót nadrealizm, lecz pokazał jego wewnętrzną niespójność ze względu na złożoność psychiki.

Uprzedmiotowienie podmiotu w literaturze i sztuce prowadzące do zerwania związku między bytem i świadomością o nim nastąpiło, począwszy od egzystencjalizmu Sartre'a, koncepcji powstałej w określonym czasie historycznym i politycznym. Sartre nadał inny kierunek monadologii Husserla i wynikającej z niej egologii. Husserl, zapożyczając termin monada od Leibniza, używal go do określenia indywidualnej całości będącej jednością podmiotowego istnienia. Monady nie stanowiły według niego całości izolowanych, a więc nie były, jak u Leibniza, monadami „bez okien”. W jego teorii kontaktują się one ze sobą, tworząc wspólnotę monad, czyli intersubiektywność monad. „Ja" stanowiące monadę charakteryzują indywidualne zdolności i możliwości oraz w pewien sposób to, co je otacza. Husserl wprowadził też rozróżnienie między własnym i cudzym ,ja". Własne ,ja” postrzegamy jako jedność aspektu fizycznego 
i psychicznego naszego ciała. Drugiego człowieka widzimy najpierw jako ciało fizyczne bezpośrednio, natomiast jego własności ujawniają się nam pośrednio. Punktem wyjścia dla postrzegania innych i świata uczynił on własne ciało. I - jak pisze Krystyna Święcicka, przytaczając Husserla:

Cudze ciało fizyczne uznaję za ciało żyjące dzięki temu, że mogę dokonać myślowego przeniesienia mojego ciała, będącego dla mnie „punktem zerowym”, na miejsce cudzego ciala fizycznego i tym samym potraktować je tak, jakbym sam się w nim znajdował. „Tym samym cudze Ja zostaje ustanowione jako analogon Ja-tam, Ja, które myślowo zostało przeniesione tam. [...] Intencjonalne przenikanie się wzajemne podmiotów [...] musi być pojęte jako zawieranie się implicite wszystkich innych podmiotów w "horyzoncie" mojego podmiotu oraz mojego podmiotu w intencjonalnym horyzoncie Innych ${ }^{11}$.

Monady były więc otwarte na siebie, tworząc wspólnotę monad, czyli podmiotowość świata. Koncepcja ta, jak nietrudno zauważyć, wpłynęła zarówno na Heideggera zadomowienie się $w$ świecie, jak również na Sartre'a kategorie bytu w sobie i bytu dla siebie. Sartre jednak zakwestionował wzajemne relacje między tymi kategoriami bytu, odbierając światu podmiotowość i możliwość kontaktu zarówno empatycznego, jak $\mathrm{i}$ intelektualnego między monadami ${ }^{12}$.

Zerwana więź komunikacyjna to człowiek pozbawiony zdolności współodczuwania, ponieważ swojego Ja nie przenosi na Ja-tam. To również stracona możliwość porozumienia, a więc urzeczowienie języka, który stracil kontakt z przedmiotem, przekonaniem, uczuciem. Traumatyzm doświadczenia wojennego umocnił taką świadomość filozoficzną; była ona także równoległa $\mathrm{z}$ odczuciami artystów. Swiat utracił spójność, a człowiek podmiotowość, stając się na przestrzeni drugiej połowy XX wieku rzeczą, ciałem, mięsem. Twórcy francuskiego teatru absurdu ogłosili światu martwą konwencjonalność i pustkę komunikacji językowej, bo język nie wyraża człowieka, lecz go zakrywa. Używa się go pour meubler la vide, o czym widz dowiadywał się ze sceny. Poezja natomiast pogłębiła tę nieufność.

Postępujące odczucie alienacji wzmocniły mass media będące wytworem ludzkiego rozumu. Również postępująca estetyzacja życia codziennego, jak chcieli tego artyści z początków wieku, coraz mniej miała wspólnego z przyjemnością przeżycia estetycznego. W rozwijającym się myśleniu hermeneutycznym zwracano wprawdzie uwagę na podwójną funkcję języka zakrywającą i odkrywającą, lecz presja dominującej coraz

11 R. Święcicka, Husserl, Warszawa 1993, s. 83, 88.

12 Por. J. P. Sartre, Czym jest literatura?, przeł. J. Lalewicz, wybór A. Tatarkiewicz, wstęp T. M. Jaroszewski, Warszawa 1968; a także T. M. Jaroszew ski, Propozycja krytyki egzystencjalnej, w: J. P. Sartre, Czym jest literatura? 
bardziej kultury masowej sprzyjała powstawaniu wtórnej rzeczywistości gotowych obrazów, sloganów wykorzystujących środki ekspresji literackiej. Przejęte przez mass media środki przedstawieniowe sztuki wywolały w sztuce i w literaturze zwrot ku dokumentowi, który miał ośmieszać mimetyzm jako metodę.

W połowie lat 50 . można zauważyć trzy formy bezpośredniego wkraczania rzeczywistości do sztuki: przez podnoszenie realnego przedmiotu do rangi sztuki (np. Flagi i Strzelnice Jaspera Johnsa, Białe groszki Różewicza); cytat z rzeczywistości dzięki wprowadzeniu do literatury takich dokumentów, jak list, pamiętnik, akt urzędowy; oraz ślad obecności podmiotu sprawczego w postaci np. odcisków twarzy, dłoni, ramienia wykorzystywanych $\mathrm{w}$ litografiach przez Jaspera Johnsa ${ }^{13}$. W liryce podmiot staje się często medium dla przepływającego przezeń świata. Rzeczywistość aktualizuje się zwykle dzięki pamięci, która wprowadza przeszłość do relacjonowanych zdarzeń czy doznań np. w Et in Arkadia ego Różewicza. Pamięć nie jest wierna, lecz względna, bo selekcjonuje rzeczywiste doznania, idealizuje i wyrywa z kontekstu. Tak mieszają się obrazy przepływające przez umysł bohatera Kartoteki. Pamięć jest również dekonstrukcją przeszłości.

Zjawiska polityczne, społeczne oraz rzeczywistość spektakli kultury masowej zaatakował ruch kontrkultury ${ }^{14}$, w ramach którego nie powstały wprawdzie wielkie dzieła sztuki, lecz stał się on inspiracją dla kultury ponowoczesnej. Ruch ten zmierzał $\mathrm{w}$ dwóch przeciwstawnych kierunkach: (1) destrukcyjnym poprzez kontestację określonych instytucji i wartości, co powodowało przeniesienie punktu ciężkości poza dzieło, na działanie (happening) lub $\mathrm{w}$ sferę pojęciową (konceptualizm); oraz (2) w kierunku konstruktywnym opartym na wykorzystaniu w twórczości znanych form artystycznych, cytatów z innych utworów. Objawiał się w dwóch formach: łagodnej, odbudowującej komunikację empatyczną (wokół „dzieci-kwiatów") oraz w postaci agresywnego buntu, z którego wyrośli późniejsi terroryści.

Po doświadczeniach politycznych, kulturowych i artystycznych XX wieku pozostała nieufność, mnożące się pytania, zaciekawienie tym, co ukryte, oraz potrzeba empatii jakby wbrew temu, co się dzieje. Niestety, głoszony szacunek i zrozumienie Innego nie idzie $w$ parze $\mathrm{z}$ nieufnością. Ponowoczesność uczyniła $\mathrm{z}$ wątpliwości podstawowe założenie, podobnie jak z niechęci do zamkniętych całości. Swiat nie jest złożony z prostych elementów, wszystko jest skomplikowane, a każda interpretacja skazana jest na redukcję. Monady coraz częściej wyrażają wolę otwarcia, lecz ob-

13 Por. B. Kowalska, Obiekt jako przedmiot wyboru artystycznego, „Biuletyn Rady Artystycznej Związku Plastyków Polskich" 1975, nr 2, s. 20-26.

14 Por. A. Jaw low ska, Drogi kontrkultury, Warszawa 1975. 
ca im jest wspólnota. Tworzą swe przestrzenie mentalne, oddalając się od wspólnot geograficznych i bezpośrednio przeżywanych, choć te nadal przecież istnieją ${ }^{15}$. Miejsce całości zajął fragment jako wynik dekonstrukcji pojęcia całości.

W literaturze i sztuce XX wieku dominuje transgresyjność, polegająca na rozszerzaniu granic wyznaczonych przez poszczególne dziedziny sztuki, a w ich zakresie przez rodzaje i gatunki. W polskiej prozie lat 90 . zwraca uwagę zjawisko zakłócenia kompozycji (dygresje w prozie Pilcha, opisy w prozie Tulli), poetyckiego czytania prozy o modelu nieepickim Magdaleny Tulli, Nataszy Goerke, Marka Bieńczyka oraz postrzeganie fabularności niekonieczne jako wyznacznika prozy. Tzw. fabulatorzy, choć przywrócili fabułę, kult intrygi i sięgają do konwencji literatury popularnej, domagają się innego czytania swoich powieści i opowiadań, by wydobyć $\mathrm{z}$ nich to, co niewypowiedziane (np. w twórczości Pawła Huellego, Olgi Tokarczuk, Izabeli Filipiak, Andrzeja Stasiuka). Często koncentrują się na przedstawianiu, a nie na tym, co przedstawione, eksponując, tak jak np. Tuziak, Wroński czy Goerke, środki zapośredniczające ekspresję ${ }^{16}$.

Literatura skupia się na doznaniach dostarczanych przez zmysły, na cielesności w swym aspekcie anatomiczno-fizjologicznym (np. w prozie Andrzeja Stasiuka, Manueli Gretkowskiej, Olgi Tokarczuk czy Jacka Baczaka). Opisy cielesności charakteryzuje neutralna postawa emocjonalna. Przypominają one notatkę służbową lub sprawozdanie, co czasem sugeruje sam tytuł np. Baczaka Zapiski z nocnych dyzurów. Czytelnik odnosi wrażenie alienacji ciała od osoby - zważywszy, że nie są to zwykle ciała piękne, odnosi swój odbiór do standardów kultury masowej17. I tutaj pojawia się problem kontekstu medialnego kształtującego tę prozę.

Wolfgang Welsch zwrócił uwagę na wytworzoną przez kulturę medialną dwoistość estetyki i anestetyki. Medialny świat obrazów tworzy wtórną rzeczywistość, w której człowiek jest monadą wypełnioną obrazami „bez okien” - jak u Leibniza - przez co słabnie kontakt z konkretna rzeczywistością. Również przestrzenie publiczne, będąc zagospodarowane estetycznie, jak chcieli tego artyści z początku wieku, otaczają i pozostawiają w człowieku obraz. Estetyzacja rzeczywistości przechodzi według Welscha w anestetyzację, co powoduje utratę zdolności doznawania, a więc warunek konieczny estetyki. Zatem anestetyzacja stanowi

15 Por. B. Kita, Między przestrzeniami. O kulturze nowych mediów, Kraków 2003 na temat nowej geografii.

${ }_{16}$ Por. P. Czapliński, Ślady przełomu. O prozie polskiej 1976-1996, Kraków 1997.

17 Por. B Witosz, Przeciw stereotypom - ku stereotypowi? (O ksztaltowaniu wizerun$k u$ postaci $w$ najnowszej prozie polskiej), w: Stereotypy $w$ literaturze (i tuz obok), red. W. Bolecki i G. Gazda, Warszawa 2003, s. 212-228. 
przekroczenie zmysłowości, pozbawiając człowieka przyjemności. Dwuznaczne wskazanie na korzyści anestetyzacji, czyli znieczulenie, pozbawia podmiot zaangażowania emocjonalnego. A więc proza lat 90 . stanowi w pewnym sensie wytwór kultury, w której estetyzacja przerodziła się w anestetyzację. Utracono zaufanie do zmysłów, bo niszczy nas to, co sprawia nam przyjemność, ponieważ w świecie medialnym zmysły utraciły „postrzegalność niebezpieczeństw”. Jak zauważył Ulrich Beck, można ją odtworzyć w sferze kultury, czyniąc - według Welscha - człowieka androgeniczną monadą ${ }^{18}$. Taka tendencja jest sprzeczna $z$ gloszoną w tym samym czasie przez Rolanda Barthes'a przyjemnością tekstu19.

Równocześnie jednak w prozę Pawła Huellego, Olgi Tokarczuk czy Jacka Baczaka wpisana jest tęsknota za tajemnicą i metafizyką. Metafizyka powraca pod koniec wieku do literatury i refleksji teoretycznej jako zakwestionowanie rozumu. Jej źródła tkwią w transcendencji człowieka i transcendencji świata. Jeden $z$ najbardziej poruszających jej obrazów daje książka Jolanty Brach-Czainy Szczeliny istnienia, wywiedziona z materialnej codzienności ludzkiej. W pewnym stopniu korespondują z nią Zapiski z nocnych dyżurów Baczaka, który inaczej stawia pytanie o to, co pozostaje $z$ człowieka, gdy jego ciało znika. Brach-Czaina na to pytanie odpowiada materialistycznie, on próbuje odnaleźć odpowiedź w Bogu i w naturze.

Można - za Barbarą Skargą - zaryzykować twierdzenie, że wątpliwości zgłaszane w kierunku racjonalizmu jako sprawcy faustycznej postawy człowieka, czyniącej go prawodawcą i wytwórcą kultury, nie mogą doprowadzić do wyeliminowania rozumu, bo dzięki niemu możemy poznać własne ograniczenia. Szkodliwe jest nadużywanie intelektu, co niewątpliwie nastąpiło, gdy wraz z powstaniem nowożytnej nauki i filozofii człowiek „uwierzył w moc rozumu, a odkrywszy gwaranta własnego istnienia we własnej myśli, jednocześnie problematyzował istnienie wszelkich otaczających go bytów"20. Wiedza, której dostarcza rozum jako racjonalne narzędzie poznania, pozwala nam na zrozumienie świata. Jej nadużycie jest zadufaniem. Racjonalizm bez metafizyki jest ograniczeniem, ponieważ metafizyka umożliwia nam zrozumienie nas samych, a dzięki temu przekroczenie materialności i ograniczenia ciała.

W prozie lat 90 . wymiar metafizyczny odkrywa się poprzez materialność ciała, codziennych wydarzeń lub magię przestrzeni fizycznych, geograficznych jak u Huellego i Tokarczuk. Anestetyzacja wielu opisów w prozie lat 90 . jako środek dotarcia do tego, co utajone, zmusza także do

18 Por. W. Welsch, Estetyka i anestetyka, przeł. M. Lukasiewicz, w: Postmodernizm. Antologie przekładów, red. R. Nycz, Kraków 1997, s. 520-546.

${ }^{19}$ Por. R. Barthes, Przyjemność tekstu, przel. A. Lewańska, Warszawa 1997.

${ }^{20} \mathrm{~B}$. Skarga, O fillozofię bać się nie musimy, Warszawa 1999, s. 24. 
weryfikacji sądów o kulturze medialnej. Arjun Apadurai, amerykański antropolog kultury, wyciąga konstruktywne wnioski $\mathrm{z}$ faktu istnienia "globalnej wioski” zauważonej już w latach 50. przez McLuhana. Globalizacji nie rozumie on jako kulturowej homogenizacji, lecz dotyczy ona różnic i budowania tożsamości społeczeństw lokalnych $\mathrm{w}$ kontakcie $\mathrm{z}$ mediami ${ }^{21}$. Kulturze $\mathrm{i}$ jednostce $\mathrm{w}$ procesie kulturowym, rozwijającym się z dużym udziałem środków technicznych, przestaje więc zagrażać unifikacja i redukcja pod warunkiem zachowania indywidualnej odrębności, lokalnej i ludzkiej. Lokalne bowiem składa się na globalne, a to, co globalne, pozwala określić inność i tożsamość tego, co lokalne. W ten sposób wprowadzone pojęcie glokalizacji, łącząc w sobie lokalne i globalne, zastępuje pojęcie globalizacji jako konceptualizacja zjawisk obecnych w aktualnej kulturze ${ }^{22}$.

Zatem protest przeciw rozumowi $\mathrm{w}$ dobie ponowoczesności wyraża potrzebę metafizyki będącej bodźcem dla zmian zachodzących w ludzkiej wiedzy.

Zadając pytania metafizyczne - jak pisze Barbara Skarga - i poszukując na nie odpowiedzi, osiągamy wyższy poziom świadomości, a więc i świadomości naszej ułomności wobec świata, a także i zła. [...] metafizyka czyni nas czułymi na inny wymiar świata, nie redukującego się do materialności rzeczy, świata wartości, ale także świata konstrukcji pojęciowych, intelektualnych [... $]^{23}$.

Autorka krytykuje więc, w innym miejscu swej książki, Jacques'a Derridę za absolutyzację anarchizmu, ponieważ wszelkie absolutyzacje prowadzą do absurdu.

O tym, że nie ma wielości bez jedności pouczał już Platon w Parmenidesie w piątej hipotezie. Bez identyczności istnienie wszelkiego bytu zmieniłoby się w pył. Zresztą zgodnie ze swoją zasadą różności postmodernista winien uznać, że wielość splata się z jednością, a identyczność z różnicą [...] $]^{24}$.

21 Por. A. Apadurai, Modernity at Large. Cultural Dimensions of Globalization, London 1997.

22 Por. R. Robertson, Globalization: Time-Space and Homogeneity-Heterogeneity, London 1995.

${ }^{23}$ B. Skarga, O filozofię bać się nie musimy..., s. 19.

24 Tamże, s. 116-117. 